\title{
Aerosol characteristics from the Taiwan aerosol supersite in the Asian yellow-dust periods of 2002
}

\author{
Chung-Te Lee ${ }^{\mathrm{a}, *}$, Ming-Tung Chuang ${ }^{\mathrm{a}}$, Chang-Chuan Chan ${ }^{\mathrm{b}}$, \\ Tsun-Jen Cheng ${ }^{\mathrm{b}}$, Song-Lih Huang ${ }^{\mathrm{c}}$ \\ ${ }^{a}$ Graduate Institute of Environmental Engineering, National Central University, 300 Jhongda Road, Jhongli, Taoyuan 32054, Taiwan \\ ${ }^{\mathrm{b}}$ Institute of Occupational Medicine and Industrial Hygiene, National Taiwan University, Taipei, Taiwan \\ ${ }^{\mathrm{c}}$ Institute of Environmental Health, National Yang Ming University, Taipei, Taiwan
}

Received 23 May 2005; accepted 4 November 2005

\begin{abstract}
The occurrence of Asian dust storms, and the subsequent transport of yellow dust (YD) greatly influences the air quality of lee-side countries such as Korea and Japan. The dust is also frequently transported in a southward direction by a strong cold high-pressure system that affects the air quality in Taiwan. This study reports the aerosol properties that were monitored continuously at the Taiwan aerosol supersite during YD events in 2002. Based on the observations of meteorology and aerosols, we divided the time interval of a YD event into a before period, during period, and after period. Among the seven observed YD events, the second event was marked with the maximum hourly $\mathrm{PM}_{10}$ level at $502 \mu \mathrm{g} \mathrm{m}^{-3}$, and with the longest during period for a total of $147 \mathrm{~h}$. The averages of the hourly $\mathrm{PM}_{10}$ and $\mathrm{PM}_{2.5-10}$ were much higher in the during period as compared to those in the before period. It is interesting to note that the time lapse in the during period was well correlated with the maximum level of both $\mathrm{PM}_{10}$ and $\mathrm{PM}_{2.5-10}$. It must be noted that the $\mathrm{PM}_{2.5}$ levels were dramatically increased in the after period, which was due to the accumulation of particles influenced by the anticyclonic outflow. The aerosol size distribution in the third YD event verified that supermicron particles dominated in the during period, and that submicron particles were predominant in the before and after periods. For the chemical properties of the aerosols, time series results indicated that sulfates were mostly contributed by the dust transport, and the others were more related to vehicle exhausts. However, they all accumulated in the period of atmospheric stagnancy.
\end{abstract}

(C) 2006 Elsevier Ltd. All rights reserved.

Keywords: Aerosol supersite; Atmospheric aerosols; Asian yellow dust; Aerosol characterization

\section{Introduction}

The source regions of the Asian yellow dust (YD) are distributed broadly over the deserts in North-

\footnotetext{
*Corresponding author. Tel.: + 88634227151 ext 34657 ; fax: +88634226551 .

E-mail address: ctlee@cc.ncu.edu.tw (C.-T. Lee).
}

west China, Inner Mongolia, and Mongolia. Based on historical records (Natsagdorj et al., 2003), the incidences of Asian dust storms occur frequently from winter to spring. The YD drawn by a dust storm is transported mostly by a Siberia high to China (Zhang et al., 2002), Korea (Kim and Park, 2001), Japan (Ma et al., 2001; Mori et al., 1999), and even further to North America (Uematsu et al., 
1983; Tratt et al., 2001). The YD is also transported by a strong continental high to Taiwan (Lin, 2001) and Hong Kong (Fang et al., 1999). Based on the weather during a YD event, as well as the nature of the dust, the arrival of the YD can be characterized by a rapid increase in $\mathrm{PM}_{10}$ level, an enhancement of the wind speed, and a reduction in relative humidity. The YD has been reported to induce an inflammation effect on pulmonary hypertensive rats (Lei et al., 2004) and might thus increase the health risk on vulnerable people. In addition, dust particles degraded visibility by solar attenuation (Kim et al., 2001), adsorbed sulfur and nitrogen during their transport (Kim and Park, 2001; Ma et al., 2001), and posed a major uncertainty in radiative forcing (Boucher and Anderson, 1996; Koloutsou-Vakakis et al., 1999).

Inspired by the concept of the US aerosol supersite program to continuously monitor aerosol properties, the Taiwan Environmental Protection Administration (TEPA) built its own aerosol supersite to investigate health risk and environmental impact from aerosols in northern Taiwan (Chan et al., 2002). The Taiwan aerosol supersite (Supersite) started planning in the year 2000 and was fully operational with loaded instruments in March 2002. Aerosol properties were continuously monitored for $\mathrm{PM}_{2.5}$ (particles with a cut-diameter of less than or equal to $2.5 \mu \mathrm{m}$ ) and $\mathrm{PM}_{10}$ (particles with a cutdiameter of less than or equal to $10 \mu \mathrm{m}$ ) mass concentrations, aerosol size distribution ranging from 0.012 to $10 \mu \mathrm{m}, \mathrm{PM}_{2.5}$ organic and elemental carbons, $\mathrm{PM}_{2.5}$ sulfate, $\mathrm{PM}_{2.5}$ nitrate, aerosol lightscattering coefficient, aerosol black carbon, and $\mathrm{PM}_{2.5}$ total polycyclic aromatic hydrocarbons. This study reports some of aerosol properties adopted from this Supersite for YD events in 2002. The objective in this work is to look into the variations of aerosol properties in different time stages of the YD events.

\section{Site location and methods}

\subsection{Site description}

Fig. 1 shows the geographical location of Taiwan and the Supersite. The Supersite is located on the ground in a park of Taipei Metropolitan Area. Two major highways contribute vehicle emissions to the Supersite, one running east-west $2-3 \mathrm{~km}$ to the north and the other $2 \mathrm{~km}$ to the south of the Supersite. The Supersite is expected to monitor ambient aerosols representing typical urban air in Taiwan. The instruments adopted in this study for data reduction are listed in Table 1. The wind speed (WS), wind direction (WD), and relative humidity (RH) in this study, however, were adopted from a nearby TEPA air quality monitoring station located $1.7 \mathrm{~km}$ southwest of the Supersite, due to the unavailability of the meteorological data at the Supersite at that specific time.

\subsection{Data collection methods}

The tapered element oscillating microbalance (TEOM) monitor is a US EPA designated $\mathrm{PM}_{10}$ equivalent method (Designation no. EQPM-1090079), which has valid measurements from above $5 \mu \mathrm{g} \mathrm{m}^{-3}$ to several $\mathrm{g} \mathrm{m}^{-3}$ (Rupprecht and Patashnick, 2002a; Jaques et al., 2004). The $\mathrm{PM}_{2.5-10}$ values were taken by subtracting the $\mathrm{PM}_{2.5}$ values out of the $\mathrm{PM}_{10}$ values. They were considered to be

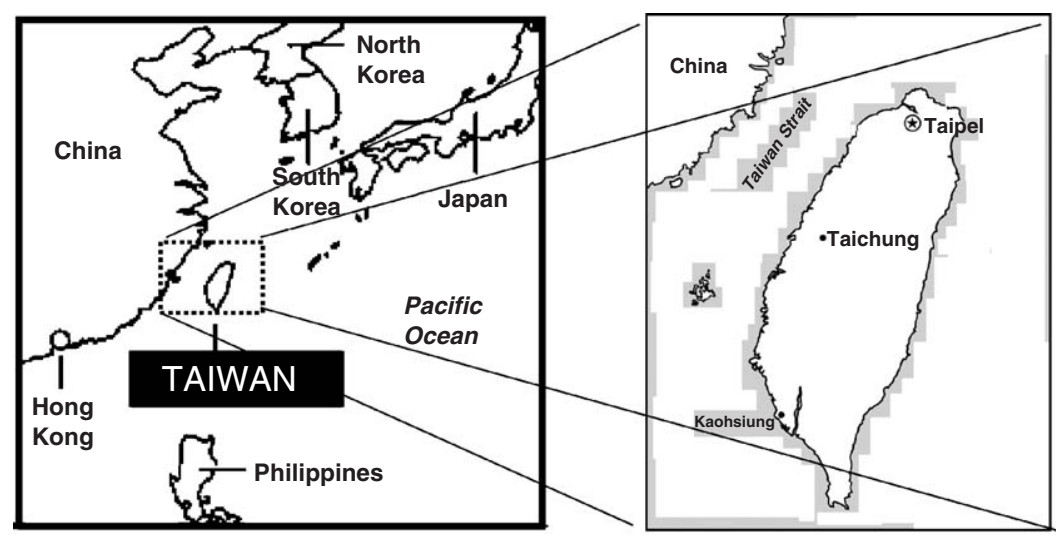

Fig. 1. Geographical location of the Taiwan aerosol supersite (marked by a star on the right panel). 
Table 1

Adopted instruments from Taiwan aerosol supersite and their monitoring capabilities

\begin{tabular}{ll}
\hline Adopted instrument & Monitoring capability \\
\hline Rupprecht \& Patashnick 1400a TEOM monitor & $\mathrm{PM}_{10}$ and $\mathrm{PM}_{2.5}$ mass concentrations \\
Rupprecht \& Patashnick 5400 ambient particulate carbon & $\mathrm{PM}_{2.5}$ total carbon, organic carbon, and elemental carbon \\
monitor & $\begin{array}{l}\mathrm{PM}_{2.5} \text { nitrate concentration } \\
\text { Rupprecht \& Patashnick 8400N particulate nitrate monitor }\end{array}$ \\
Rupprecht \& Patashnick 8400S particulate sulfate monitor & $\mathrm{PM}_{2.5}$ sulfate concentration \\
PMS PCASP-X aerosol spectrometer & Aerosol size distribution from 0.10 to $10 \mu \mathrm{m}$ \\
\hline
\end{tabular}

with the similar precision in $\mathrm{PM}_{10}$ measurements. All instruments for aerosol speciation were equipped with a $\mathrm{PM}_{10}$ inlet followed by a sharp cut cyclone to collect ambient $\mathrm{PM}_{2.5}$. Both aerosol nitrate and sulfate concentration from R\&P $8400 \mathrm{~N}$ Ambient Particulate Nitrate Monitor and 8400S Ambient Particulate Sulfate Monitor have a base line stability of $0.4 \mu \mathrm{g} \mathrm{m}^{-3}$ and a measurement resolution of $0.2 \mu \mathrm{g} \mathrm{m}^{-3}$ (Rupprecht and Patashnick, 2001a, b). For aerosol carbon measurements, Rice (2004) indicated the method detection limit of R\&P 5400 Ambient Particulate Carbon Monitor by citing the estimate from the manufacture as $0.10 \mu \mathrm{g} \mathrm{C} \mathrm{m}^{-3}$. The concentration of organic carbon (OC) in this study is the concentration of particulate carbon $\left(\mu \mathrm{g} \mathrm{C} \mathrm{m}^{-3}\right)$ in ambient air without converting into organic matter. During the analysis phase of the instrument, the temperature of the collector is raised to $340^{\circ} \mathrm{C}$ for a period of $780 \mathrm{~s}$ for $\mathrm{OC}$ detection and $750{ }^{\circ} \mathrm{C}$ for $480 \mathrm{~s}$ for total carbon (TC) detection. The $\mathrm{CO}_{2}$ released at the heating of the collected particles is measured by a non-disperse infrared (NDIR) $\mathrm{CO}_{2}$ detector (Rupprecht and Patashnick, 2002b). The concentration of elemental carbon (EC) was obtained by subtracting the OC values out of the TC values. Aerosol size distribution is measured by the PMS PCASP-X Aerosol Spectrometer (Particle Measuring Systems, 2001). This spectrometer is capable of sizing particles over a size range from 0.1 to $10.0 \mu \mathrm{m}$ in 31 size channels. A $\mathrm{He}-\mathrm{Ne}(632.8 \mathrm{~nm})$ laser is installed into the instrument for particle detection with the minimum detectable size at $0.1 \mu \mathrm{m}$.

\subsection{Data analysis}

To compare the aerosol properties in different time periods of a YD event, we divided the time interval of a YD event into before, during, and after periods. The before period is defined as $24 \mathrm{~h}$ prior to the occurrence of a YD event. The occurrence of a YD event is initiated by the sudden rise of $\mathrm{PM}_{2.5-10}$, the change of WD, and the increase of WS. The during period is then characterized by the intermittent rise of $\mathrm{PM}_{2.5-10}$ and $\mathrm{WS}$ and a relatively steady WD. The termination of the during period is justified by the fall of $\mathrm{PM}_{2.5-10}$ and the resumption of WD and WS to the levels in the before period. The after period is dominated by the atmospheric stagnancy brought about by the anticyclonic outflow following the during period. In 2002, TEPA officially declared eight YD events affecting Taiwan's air quality. Table 2 shows the dates, the before, the during, and the after periods of each YD event. Among the eight YD events, the Supersite was able to monitor aerosol properties from the second to the eighth YD events.

\section{Results and discussion}

\subsection{Statistics of aerosol properties and meteorological parameters monitored in YD events in 2002}

Table 3 shows the basic statistics of aerosol properties and meteorological parameters for the three time periods of each YD event in this study. Since the strength of a YD event can be indicated by the rapid rise in $\mathrm{PM}_{2.5-10}$, we calculated the maximum and the average hourly $\mathrm{PM}_{2.5-10}$ levels in the during period, they were 443 and $81 \mu \mathrm{g} \mathrm{m}^{-3}$, respectively. By comparing the $\mathrm{PM}_{2.5-10}$ levels between the before and the during periods, the enhancement was found to be around seven times and four times for the maximum and the average values, respectively. This exemplifies the impact of particulate matter during the YD events in 2002. The $\mathrm{PM}_{2.5}$ level, however, exhibited its highest value in the after period as a result of the poor ventilation under anticyclonic outflow. In addition, 
Table 2

The three time periods for each Asian yellow-dust event affecting Taiwan in 2002

\begin{tabular}{|c|c|c|c|c|}
\hline \multirow[t]{2}{*}{ Event } & \multirow[t]{2}{*}{ Event dates $^{\mathrm{a}}$} & \multicolumn{3}{|c|}{ Periods of the yellow-dust event } \\
\hline & & Before period ${ }^{\mathrm{b}}$ & During period $^{\mathrm{c}}$ & After period $^{\mathrm{d}}$ \\
\hline 1 & $2 / 11-2 / 12$ & $2 / 1011: 00-2 / 1111: 00(24)^{\mathrm{e}}$ & 2/11 11:00-2/12 11:00 (24) & $2 / 12$ 19:00-2/13 12:00 (17) \\
\hline 2 & $3 / 6-3 / 9$ & $3 / 501: 00-3 / 601: 00(24)$ & $3 / 601: 00-3 / 1204: 00(147)$ & $3 / 1204: 00-3 / 12 \quad 20: 00(40)$ \\
\hline 3 & $3 / 18-3 / 20$ & $3 / 1623: 00-3 / 17$ 23:00 (24) & $3 / 1723: 00-3 / 1922: 00(47)$ & $3 / 1922: 00-3 / 21 \quad 10: 00(36)$ \\
\hline 4 & $3 / 23-3 / 24$ & $3 / 2201: 00-3 / 2301: 00(24)$ & $3 / 23$ 01:00-3/23 20:00 (19) & $3 / 2403: 00-3 / 250: 00(21)$ \\
\hline 5 & $3 / 31-4 / 1$ & $3 / 3006: 00-3 / 3105: 00$ (24) & $3 / 3105: 00-4 / 1 \quad 1: 00(20)$ & 4/1 05:00-4/3 09:00 (52) \\
\hline 6 & $4 / 8-4 / 10$ & 4/8 08:00-4/9 08:00 (24) & 4/9 08:00-4/11 1:00 (41) & 4/11 01:00-4/12 01:00 (24) \\
\hline 7 & $4 / 11-4 / 15$ & 4/11 20:00-4/12 19:00 (24) & 4/12 19:00-4/14 03:00 (32) & 4/14 03:00-4/16 08:00 (53) \\
\hline 8 & $4 / 17-4 / 19$ & 4/17 04:00-4/18 03:00 (24) & $4 / 18 \quad 03: 00-4 / 18 \quad 10: 00(7)$ & $4 / 2002: 00-4 / 2108: 00(30)$ \\
\hline
\end{tabular}

the mass fraction of major $\mathrm{PM}_{2.5}$ species (carbons + sulfate + nitrate) varied from $58 \%$ in the before period down to $43 \%$ in the during period and went back to $64 \%$ in the after period. This indicates a shift from the dominance of the secondary aerosol species to dust related species as the air mass changes from the non-dust period to the dust period.

\section{2. $P M_{10}$ and $P M_{2.5}$ levels for the three periods of $Y D$ events in 2002}

Fig. 2 shows the frequency distribution of $\mathrm{PM}_{10}$ levels for the three time periods of the seven YD events in 2002. It shows that the $\mathrm{PM}_{10}$ level is the highest in the during period of the second YD event. Back trajectory analysis (Draxer, 1999) indicates that the air masses at 2000 and $1500 \mathrm{~m}$ were transported from Inner Mongolia through China's industrial coastline before coming down to Taiwan (not shown). As the barometric pressure of the second YD event is the greatest among all seven YD events, we believe that the high $\mathrm{PM}_{10}$ level in the second event is probably related to the strength of the high-pressure system. At the same time, the during period $\mathrm{PM}_{10}$ level is always higher than that of the before period. Among the seven YD events observed from the Supersite, the fourth and fifth ones were the least two severe events due to the rains in the during period. A similar rain scavenging effect is also found for the lowest level of $\mathrm{PM}_{10}$ in the after period of the sixth event. Fig. 3 shows the frequency distribution of the $\mathrm{PM}_{2.5}$ levels for the three time periods of the YD events in 2002. It is worth noting that the after period $\mathbf{P M}_{2.5}$ level is always higher than that of the other two periods, except for the sixth event which was due to rains. It should also be noted that the highest $\mathrm{PM}_{2.5}$ is in the after period of the third event, while the highest $\mathrm{PM}_{10}$ is in the during period of the second event. This indicates that the intensity of the YD event is not crucial in the determination of the $\mathrm{PM}_{2.5}$ level in the after period. Since $\mathrm{PM}_{2.5}$ poses much more of a health concern than $\mathrm{PM}_{10}$, we must remind people of the health threat during the after period of a YD event. The weather in the after period has frequently been affected by an anticyclonic outflow. When a highpressure system moves in from the Asian continent, it is usually a cold high. However, as this continental high moves out from the Asian continent to the West Pacific, it changes from cold to warm. At the same time, the peripheral circulation of the high-pressure system turns from southerly direction to a westerly direction. This is characterized by a northeastern wind when this anticyclonic outflow reaches the northern part of Taiwan's coast. Since the weather under an anticyclonic outflow is stagnant and warm, it is considered to provide a favorable environment for the formation of secondary aerosols. Therefore, it is the poor atmospheric ventilation caused by the subsidence of the air mass, which accounts for the accumulation of $\mathrm{PM}_{2.5}$. 
Table 3

Basic statistics of aerosol properties and meteorological parameters monitored in yellow-dust events in 2002

\begin{tabular}{|c|c|c|c|c|c|c|}
\hline Measurement item & Unit & Duration of time (h) & Average $( \pm$ standard deviation $)$ & Max. & Min. & Percentage $(\%)$ in $\mathrm{PM}_{2.5}$ \\
\hline \multicolumn{7}{|l|}{ Before period } \\
\hline $\mathrm{PM}_{2.5-10}{ }^{\mathrm{a}}$ & $\mu \mathrm{g} \mathrm{m}^{-3}$ & 157 & $18( \pm 13)$ & 63 & 2 & - \\
\hline $\mathrm{PM}_{2.5}$ & $\mu \mathrm{g} \mathrm{m}^{-3}$ & 162 & $26( \pm 15)$ & 75 & 3 & 100 \\
\hline TC-PM 2.5 & $\mu \mathrm{g} \mathrm{C} \mathrm{m}^{-3}$ & 126 & $7( \pm 3)$ & 18 & 2 & 28 \\
\hline $\mathrm{OC}-\mathrm{PM}_{2.5}$ & $\mu \mathrm{g} \mathrm{C} \mathrm{m}^{-3}$ & 126 & $6( \pm 2)$ & 13 & 2 & 21 \\
\hline $\mathrm{EC}-\mathrm{PM}_{2.5}$ & $\mu \mathrm{g} \mathrm{C} \mathrm{m}^{-3}$ & 126 & $2( \pm 1)$ & 6 & $<1$ & 7 \\
\hline $\mathrm{OC} / \mathrm{EC}-\mathrm{PM}_{2.5}$ & Ratio & 126 & $4( \pm 2)$ & 15 & 2 & - \\
\hline Sulfate- $\mathrm{PM}_{2.5}$ & $\mu \mathrm{g} \mathrm{m}^{-3}$ & 144 & $6( \pm 4)$ & 14 & 1 & 22 \\
\hline Nitrate- $\mathrm{PM}_{2.5}$ & $\mu \mathrm{g} \mathrm{m}^{-3}$ & 161 & $2( \pm 2)$ & 12 & $<1$ & 8 \\
\hline Temperature & ${ }^{\circ} \mathrm{C}$ & 161 & $21( \pm 4)$ & 33 & 15 & - \\
\hline Wind speed & $\mathrm{ms}^{-1}$ & 167 & $1( \pm 1)$ & 3 & $<0.1$ & - \\
\hline $\mathrm{RH}^{\mathrm{b}}$ & $\%$ & 161 & $77( \pm 14)$ & 94 & 29 & - \\
\hline \multicolumn{7}{|l|}{ During period } \\
\hline $\mathrm{PM}_{2.5-10^{\mathrm{a}}}$ & $\mu \mathrm{g} \mathrm{m}^{-3}$ & 308 & $81( \pm 65)$ & 443 & 12 & - \\
\hline $\mathrm{PM}_{2.5}$ & $\mu \mathrm{g} \mathrm{m}^{-3}$ & 314 & $34( \pm 14)$ & 83 & 4 & 100 \\
\hline TC-PM 2.5 & $\mu \mathrm{g} \mathrm{C} \mathrm{m}^{-3}$ & 289 & $7( \pm 4)$ & 29 & 1 & 19 \\
\hline $\mathrm{OC}-\mathrm{PM}_{2.5}$ & $\mu \mathrm{gC} \mathrm{m}^{-3}$ & 289 & $5( \pm 3)$ & 19 & $<1$ & 14 \\
\hline $\mathrm{EC}-\mathrm{PM}_{2.5}$ & $\mu \mathrm{g} \mathrm{C} \mathrm{m}^{-3}$ & 289 & $2( \pm 1)$ & 10 & $<1$ & 5 \\
\hline $\mathrm{OC} / \mathrm{EC}-\mathrm{PM}_{2.5}$ & Ratio & 289 & $3( \pm 1)$ & 8 & 1 & - \\
\hline Sulfate- $\mathrm{PM}_{2.5}$ & $\mu \mathrm{g} \mathrm{m}^{-3}$ & 290 & $7( \pm 4)$ & 18 & 1 & 19 \\
\hline Nitrate- $\mathrm{PM}_{2.5}$ & $\mu \mathrm{g} \mathrm{m}^{-3}$ & 312 & $1( \pm 1)$ & 8 & $<1$ & 4 \\
\hline Temperature & ${ }^{\circ} \mathrm{C}$ & 319 & $20( \pm 4)$ & 29 & 13 & - \\
\hline Wind speed & $\mathrm{m} \mathrm{s}^{-1}$ & 318 & $2( \pm 1)$ & 6 & $<0.1$ & - \\
\hline $\mathrm{RH}^{\mathrm{b}}$ & $\%$ & 312 & $56( \pm 17)$ & 99 & 5 & - \\
\hline \multicolumn{7}{|l|}{ After period } \\
\hline $\mathrm{PM}_{2.5-10}{ }^{\mathrm{a}}$ & $\mu \mathrm{g} \mathrm{m}^{-3}$ & 259 & $24( \pm 13)$ & 71 & 1 & - \\
\hline $\mathrm{PM}_{2.5}$ & $\mu \mathrm{g} \mathrm{m}^{-3}$ & 268 & $51( \pm 29)$ & 144 & 5 & 100 \\
\hline TC-PM 2.5 & $\mu \mathrm{gCm}^{-3}$ & 263 & $17( \pm 11)$ & 73 & 2 & 33 \\
\hline $\mathrm{OC}-\mathrm{PM}_{2.5}$ & $\mu \mathrm{g} \mathrm{C} \mathrm{m}^{-3}$ & 263 & $12( \pm 7)$ & 40 & 2 & 24 \\
\hline $\mathrm{EC}-\mathrm{PM}_{2.5}$ & $\mu \mathrm{g} \mathrm{C} \mathrm{m}^{-3}$ & 263 & $5( \pm 4)$ & 33 & $<1$ & 9 \\
\hline $\mathrm{OC} / \mathrm{EC}-\mathrm{PM}_{2.5}$ & Ratio & 263 & $3( \pm 2)$ & 19 & 1 & - \\
\hline Sulfate- $\mathrm{PM}_{2.5}$ & $\mu \mathrm{g} \mathrm{m}^{-3}$ & 256 & $10( \pm 5)$ & 23 & 1 & 19 \\
\hline Nitrate- $\mathbf{P M}_{2.5}$ & $\mu \mathrm{g} \mathrm{m}^{-3}$ & 270 & $6( \pm 6)$ & 24 & $<1$ & 13 \\
\hline Temperature & ${ }^{\circ} \mathrm{C}$ & 273 & $23( \pm 4)$ & 33 & 16 & - \\
\hline Wind speed & $\mathrm{m} \mathrm{s}^{-1}$ & 268 & $1( \pm 1)$ & 4 & $<0.1$ & - \\
\hline $\mathrm{RH}^{\mathrm{b}}$ & $\%$ & 269 & $70( \pm 16)$ & 96 & 28 & - \\
\hline
\end{tabular}

${ }^{\mathrm{a}} \mathrm{PM}_{2.5-10}$ was obtained from the subtraction of $\mathrm{PM}_{2.5}$ from $\mathrm{PM}_{10}$.

${ }^{\mathrm{b}} \mathrm{RH}$ denotes relative humidity.

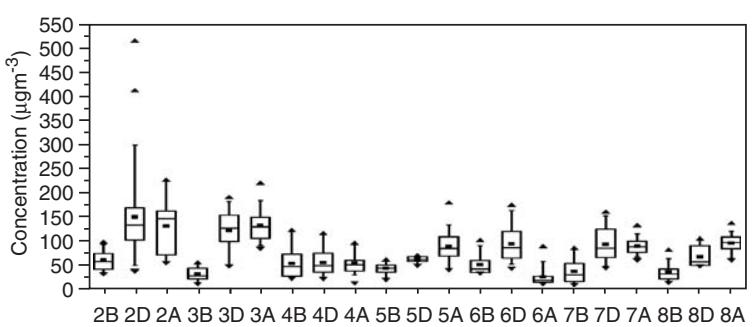

Fig. 2. $\mathrm{PM}_{10}$ frequency distribution for each yellow-dust period in 2002 (2-8: the number of the yellow-dust event, B: before period, D: during period, A: after period. The horizontal lines in each box represent the 95 th, 75 th, 50th, 25th, and 5th percentiles, respectively, from top to bottom. The max value $(\boldsymbol{\Delta})$, min value $(\boldsymbol{\nabla})$, and average value ( $\boldsymbol{\square})$ are also shown.

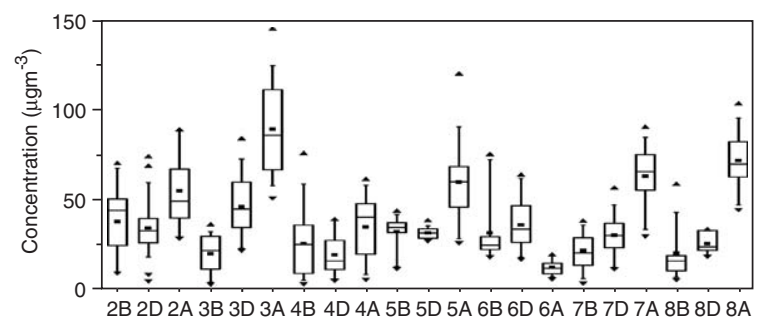

Fig. 3. $\mathrm{PM}_{2.5}$ frequency distribution for each yellow-dust period in 2002. The notations, symbols, and lines are the same as Fig. 2.

In order to investigate the coarse particle contribution during YD events, we compared the $\mathrm{PM}_{2.5-10}$ values with the $\mathrm{PM}_{2.5}$ values in Fig. 4. It 


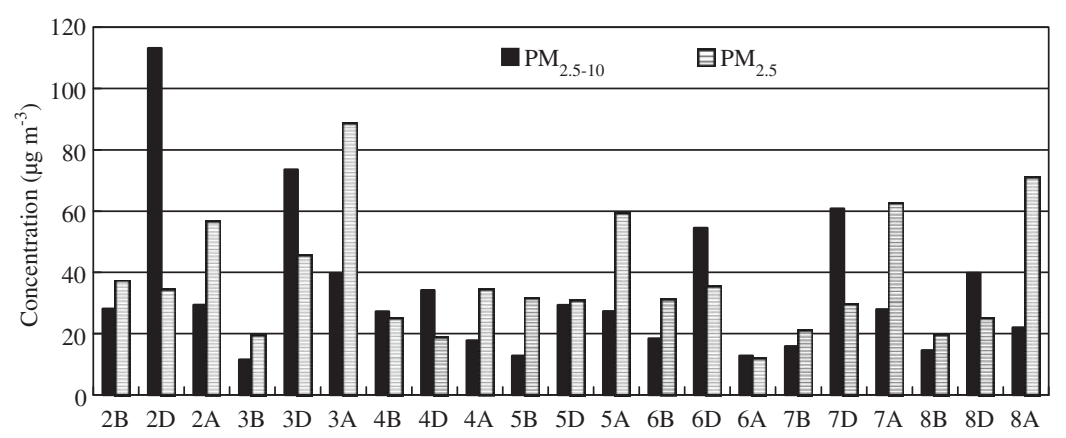

Fig. 4. Average concentration of $\mathrm{PM}_{2.5-10}$ (the difference between $\mathrm{PM}_{10}$ and $\mathrm{PM}_{2.5}$ ) and $\mathrm{PM}_{2.5}$ for each yellow-dust period in 2002 (2-8: the number of the yellow-dust event, B: before period, D: during period, A: after period).

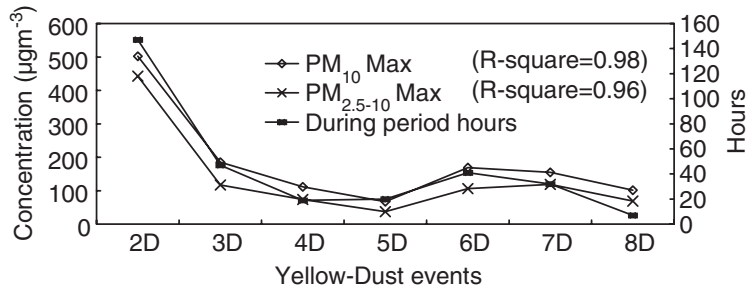

Fig. 5. Aerosol maximum concentration and the hours in the during period for each dust event in 2002.

clearly shows that $\mathrm{PM}_{2.5-10}$ was dominant in the $\mathrm{PM}_{10}$ in the during period, except for the fifth event due to rains. As evident in the $\mathrm{PM}_{2.5-10}$ level for the during period in Fig. 4, the second and the third events had the highest PM levels observed in Taiwan in 2002. Statistical analysis shows that a high correlation is found between $\mathrm{PM}_{2.5-10}$ and $\mathrm{PM}_{10}\left(r^{2}=0.96\right)$, but that it is low between $\mathrm{PM}_{2.5}$ and $\mathrm{PM}_{10}\left(r^{2}=0.18\right)$ in the during period. This is in contrast to the high correlation between $\mathrm{PM}_{2.5}$ and $\mathrm{PM}_{10}$ in the before and after periods.

\subsection{The relationship between the maximum hourly $P M$ level and the hours of the during period}

It is necessary for TEPA to know the duration of a YD period in order to call off the warning once it is issued to the general public. As one can find from Table 2, the during period of a YD event is variable. Among the YD events in 2002, the during period of the second YD event with $147 \mathrm{~h}$ was the longest. The maximum $\mathrm{PM}_{10}$ and $\mathrm{PM}_{2.5-10}$ levels were also the highest for the second YD event over all. In contrast, the eighth YD event was the one with the shortest during period, and its maximum $\mathrm{PM}_{10}$ and $\mathrm{PM}_{2.5-10}$ levels were the smallest. If we compare the maximum hourly $\mathrm{PM}_{10}$ and $\mathrm{PM}_{2.5-10}$ levels with the hours in the during period in Fig. 5 we find a strong correlation between them $\left(r^{2}=0.98\right.$ for $\mathrm{PM}_{10}$ and 0.96 for $\mathrm{PM}_{2.5-10}$ ). This implies that one can predict the duration of a YD event simply by referring to its maximum hourly $\mathrm{PM}_{10}$ level in the during period. This finding may help authorities to figure out the duration that the YD will influence the local population.

\subsection{Continuous aerosol properties and meteorological parameters in the second YD event}

Since the duration was the longest and the dust level was the highest in the second YD event, we report the continuous aerosol properties and meteorological parameters for this event. As the YD was transported to Taiwan by a continental high-pressure system in a southerly direction from the dust source region, we checked the synoptic weather map, and found that on the verge of the start of the second YD event, the cold front reached Taiwan at 14:00 (local time) on 5 March 2002 (not shown). It was this continental high-pressure system which brought the YD to Taiwan. On the arrival of the second YD, the WD changed from west to northeast, and the WS increased from 1 to $2-3 \mathrm{~m} \mathrm{~s}^{-1}$ as shown in Fig. 6(a). However, the influence of the YD started at 02:00 on 6 March 2002, as determined by the rapid increase of $\mathrm{PM}_{2.5-10}$ (Fig. 6(b)). This rapid accumulation of coarse particles was different from the dominant $\mathrm{PM}_{2.5}$ observed in the before period. The up and down of the $\mathrm{PM}_{2.5-10}$ levels from March 6-12 indicates an intermittent deposit of dust particles in the during period. This implies that the dust was transported in puffs by the air mass. Except for the peaks of $\mathrm{PM}_{2.5-10}$ and $\mathrm{PM}_{2.5}$ in the early morning of March 6, the other peaks of $\mathrm{PM}_{2.5-10}$ and $\mathrm{PM}_{2.5}$ for the rest of this YD event 

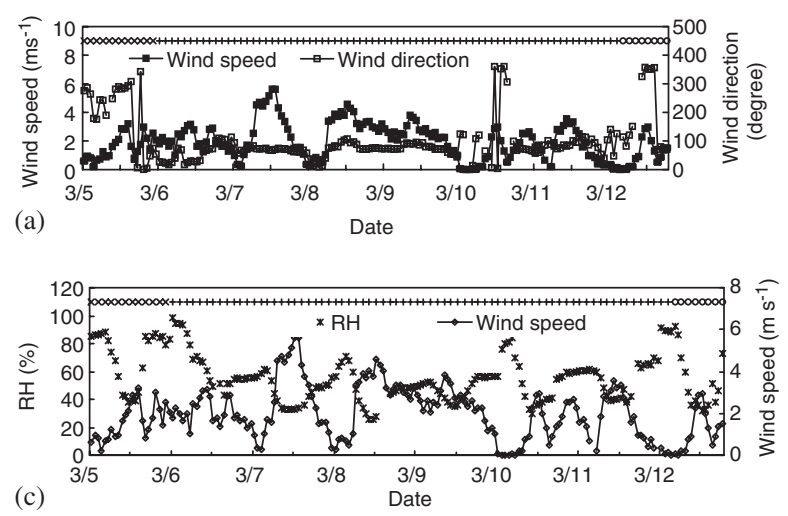
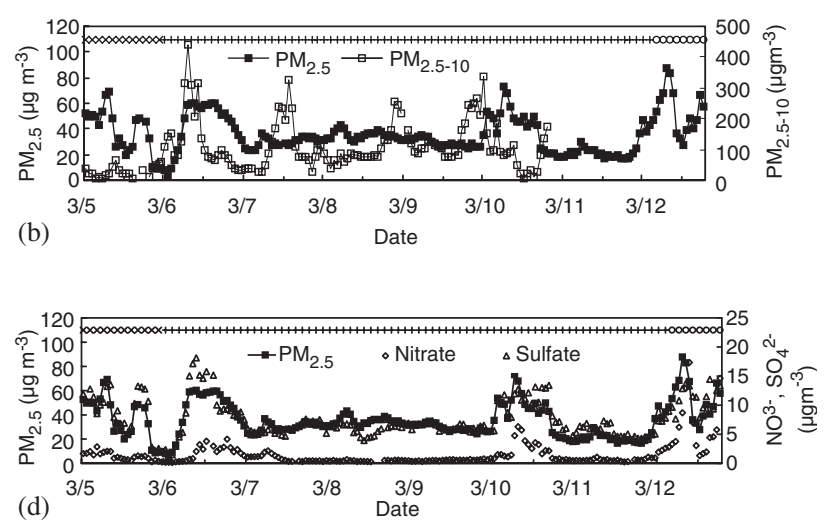

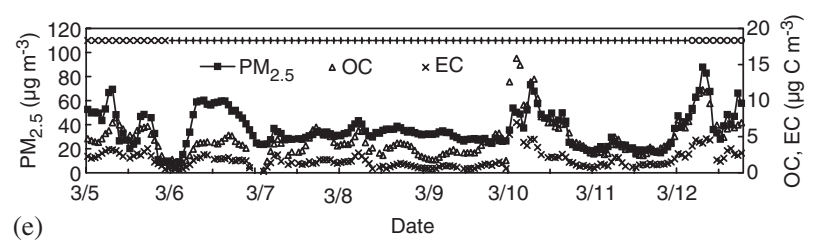

Fig. 6. Time variations of wind speed and wind direction (a), $\mathrm{PM}_{2.5}$ and $\mathrm{PM}_{2.5-10}$ (b), wind speed and relative humidity (c), $\mathrm{PM}_{2.5}$, $\mathrm{PM}_{2.5}$ sulfate, and $\mathrm{PM}_{2.5}$ nitrate (d), $\mathrm{PM}_{2.5}, \mathrm{PM}_{2.5}$ organic carbon (OC), and $\mathrm{PM}_{2.5}$ elemental carbon (EC) (e) monitored at the Taiwan aerosol supersite for the second yellow-dust event in 2002. In each graph, "x" denotes the time interval for the before period, " +" stands for the time interval for the during period, and "o" exhibits the time interval for the after period.

occurred at different times. This indicates different source contributions for $\mathrm{PM}_{2.5-10}$ and $\mathrm{PM}_{2.5}$ for this event. Fig. 6(c) shows the hourly variations of both relative humidity $(\mathrm{RH})$ and WS for the second YD event. It is of interest to note that both parameters were complimentary in the course of this event. When comparing Fig. 6(b) with (c), it is evident that high $\mathrm{PM}_{2.5}$ levels were associated with high RH and low WS except for the first peak on March 6. This shows that the accumulation of $\mathrm{PM}_{2.5}$ in the second YD event was aggravated due to atmospheric stagnancy and high $\mathrm{RH}$. The airmass on the early morning on March 6 originated from Inner Mongolia and then moved along China's industrial coastline to Taiwan. It is from the first puff of this air mass moving along this path that we observed a simultaneous rise of both $\mathrm{PM}_{2.5-10}$ and $\mathrm{PM}_{2.5}$ when it arrived in Taiwan on March 6. Fig. 6(d) shows that sulfate is the major constituent of $\mathrm{PM}_{2.5}$, both in the first puff of the second YD event and in the other peaks of $\mathrm{PM}_{2.5}$. Because the level of $\mathrm{PM}_{2.5}$ observed on March 12 was so high, we referred to the back trajectory on this date in order to trace back the movements of this air mass. The 72-h back trajectory (Draxer, 1999) on March 12 originated in the south of Korea and moved along the Pacific Ocean for most of the time (not shown). Since the air mass passed a clean ocean area, no anthropogenic sources were expected to contribute to the observed high $\mathrm{PM}_{2.5}$ level. On the other end, the trajectory path showed that the air mass was influenced by the anticyclonic outflow. The $\mathrm{PM}_{2.5}$ sulfates for the peaks, other than those in the early morning on March 6, were thus due to the atmospheric stagnancy that had resulted from the anticyclonic outflow. Other than the time variations of $\mathrm{PM}_{2.5}$ sulfate, the $\mathrm{PM}_{2.5}$ nitrate did not show a high concentration in the dusts, but it peaked in the morning on March 10 and 12. This demonstrates that the $\mathrm{PM}_{2.5}$ nitrate was not transported from the dusts but had accumulated from local activities. Fig. 6(e) shows the time variations of $\mathrm{PM}_{2.5}, \mathrm{PM}_{2.5}$ OC, and $\mathrm{PM}_{2.5}$ EC. The $\mathrm{PM}_{2.5}$ OC generally follows the variations of $\mathrm{PM}_{2.5}$ except for the time when the YD hit in the early morning on March 6. Since $\mathrm{PM}_{2.5}$ was mostly contributed from local activities, it can be concluded that the $\mathrm{PM}_{2.5}$ OC was not a major constituent in the transported dusts. The $\mathrm{PM}_{2.5}$ EC shows lower values than the $\mathrm{PM}_{2.5} \mathrm{OC}$ in the time period of the second dust event, however, it peaks in the morning of each day, reflecting the influence of vehicle emissions during the rush hours. The $\mathrm{PM}_{2.5}$ EC also shows a higher level in the early morning on March 10, a phenomenon as a result of the atmospheric temperature inversion. From our investigation on $\mathrm{PM}_{2.5}$ and its chemical properties 
in the after period of seven YD events in 2002, their peak values usually occurred at 10:00 a.m. and 1:00 p.m. on each day. The former is due to the contribution of vehicle exhausts from the morning rush hour, and the latter can be attributed to low WS and photochemical reaction, because the daily maximum $\mathrm{O}_{3}$ was greater than the monthly average of the daily maximum in these time periods.

\subsection{Aerosol size distribution in a YD event}

To understand the variations in aerosol size distribution during a YD event, we extracted aerosol number size distributions measured by the PMS PCASP-X aerosol spectrometer and converted them into aerosol volume size distributions by assuming that the particles are spherical in shape. Owing to incomplete data retrieval in the second YD event, we choose to show the aerosol size distributions of the third YD event in Fig. 7. For a rough split by size, the aerosol volume can be divided into submicron and supermicron modes in Fig. 7. The aerosol volume size spectra of the submicron mode in the during period is similar in amount to the before period. However, in the supermicron mode, the aerosol volume clearly exceeds that of the before and after periods. When taking into consideration the aerosol production mechanism, there are three modes in the aerosol volume size distribution throughout the event period. Two peak diameters at 0.4 and $0.7-0.8 \mu \mathrm{m}$, respectively, can be identified in the submicron mode. The $0.4 \mu \mathrm{m}$ size is considered to have grown from condensation nuclei, and the $0.7-0.8 \mu \mathrm{m}$ particles are thought to be from droplet reaction (McMurry and Wilson, 1982; Morawska et al., 1998). In the coarse mode, the peak diameter in the $2-3 \mu \mathrm{m}$ range must be associated with dusts, since a drastic increase in this mode was observed in the during period. To compare the measured aerosol number count with the collected mass, we divided the optical size by the square root of the particle density to obtain particle size that is equivalent to aerodynamic diameter. We then converted the aerosol volume into mass by multiplying the particle density. By assuming an average density of coarse particles at $2.6 \mathrm{~g} \mathrm{~cm}^{-3}$, we obtained an average particle mass concentration at $34 \mu \mathrm{g} \mathrm{m}^{-3}$, and a maximum value at $62 \mu \mathrm{g} \mathrm{m}^{-3}$. The value of $2.6 \mathrm{~g} \mathrm{~m}^{-3}$ for coarse particles was based on the suggestion from Ranz and Wong (1952) in Okada and Kai (2004) for mineral particles and on the density of
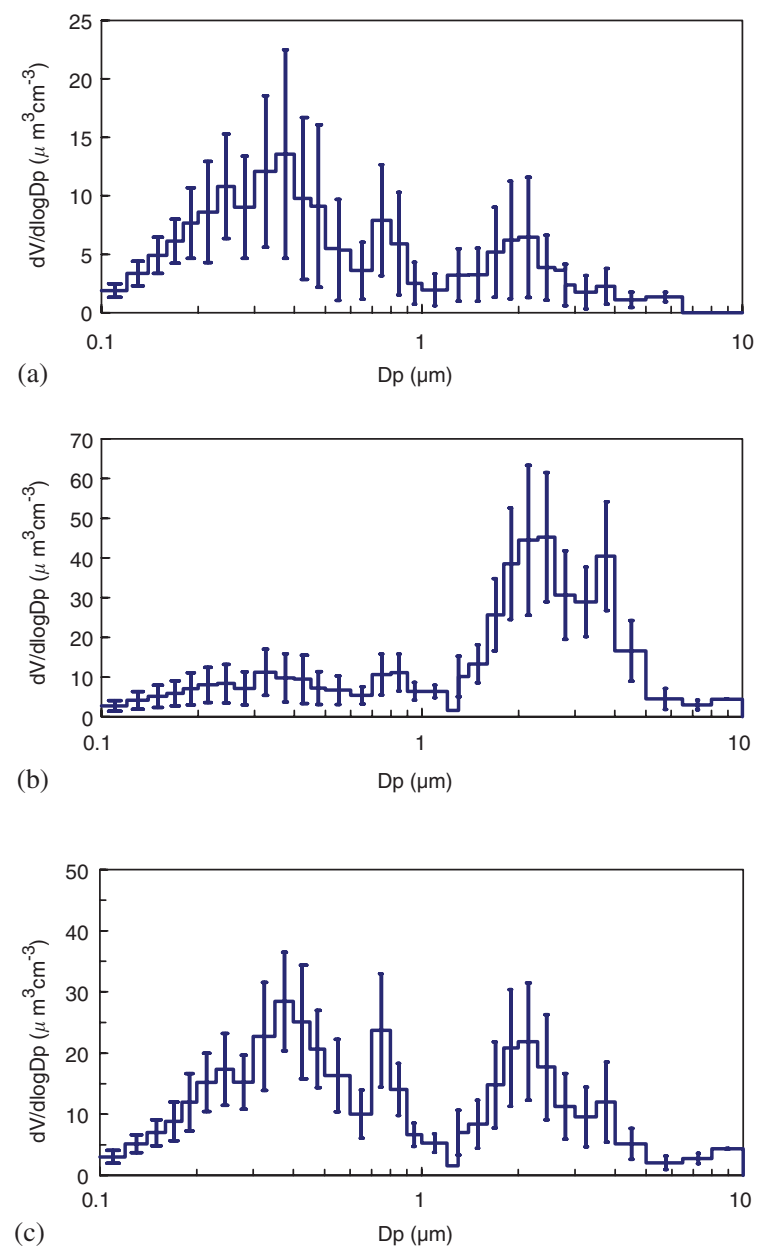

Fig. 7. Aerosol volume size distributions for the before period (a), during period (b), and after period (c) in the third yellow-dust event from 18 to 20 March 2002.

quartz at $2.65 \mathrm{~g} \mathrm{~cm}^{-3}$ (Weast and Astle, 1983). Similarly, we obtained an average particle mass concentration at $20 \mu \mathrm{g} \mathrm{m}^{-3}$ and a maximum value of $39 \mu \mathrm{g} \mathrm{m}^{-3}$ in the fine mode for the average particle density at $2.0 \mathrm{~g} \mathrm{~cm}^{-3}$. The density of fine particles chosen at $2.0 \mathrm{~g} \mathrm{~m}^{-3}$ was adopted from the density of the important species in fine particles like ammonium sulfate $\left(1.76 \mathrm{~g} \mathrm{~cm}^{-3}\right)$, ammonium nitrate $\left(1.73 \mathrm{~g} \mathrm{~cm}^{-3}\right)$ (Weast and Astle, 1983), and the possible mix of small-sized mineral dusts in the fine particles. The sum of the two numbers in the coarse and fine modes approximates a $\mathrm{PM}_{10}$ average at $54 \mu \mathrm{g} \mathrm{m}^{-3}$, and a maximum value at $101 \mu \mathrm{g} \mathrm{m}^{-3}$. In contrast, the average $\mathrm{PM}_{10}$ value was $119 \mu \mathrm{g} \mathrm{m}^{-3}$ and the maximum value was $185 \mu \mathrm{g} \mathrm{m}^{-3}$ for the during period in the third YD event (Fig. 2). The converted aerosol mass concentration from 
the number count is around half of that from the R\&P 1400a TEOM mass monitor. The irregular shape of yellow dusts deviates from the assumption of spherical shape of particles detected by the optical aerosol spectrometer used in this study. An evaluation of particle shape effect on the conversion of particle mass from particle number count is conducted in this study. A dynamic shape factor $\left(F_{\mathrm{D}}\right)$ is normally used to relate physical diameter to the aerodynamic diameter of an aerosol particle (Davies, 1979). The ratio of particle mass collected by weighing $\left(W_{\mathrm{W}}\right)$ and particle mass calculated from counting $\left(W_{\mathrm{C}}\right)$ is proportional to the square root of the ratio between $F_{\mathrm{D}}^{3}$ and the density of the particles (Yang et al., 2004). For a value of $F_{\mathrm{D}}$ at 1.41 (Davies, 1979) and the density of dust particles at $2.6 \mathrm{~g} \mathrm{~m}^{-3}$, we find the value of $W_{\mathrm{W}} / W_{\mathrm{C}}$ is 1.04 . Therefore, the effect of particle shape cannot account for the large difference between the calculated and measured particle mass concentrations in this study. In addition, the index of refraction of quartz, ammonium sulfate, and polystyrene latex spheres (for the calibration of the PMS PCASP-X Aerosol Spectrometer) are 1.54, 1.52, and 1.59 , respectively (Weast and Astle, 1983). They are not significantly different from each other to explain the difference, either. Therefore, we think the deviation might be due to different detection principles between the two instruments, as well as inefficient counting by the laser aerosol spectrometer when particles are dense in the flow such as the case with dust.

\section{Conclusions}

We reported here for the first time the comprehensive Taiwan aerosol supersite data from the YD events in 2002. Seven out of eight dust events were monitored to show aerosol mass in $\mathrm{PM}_{10}$ and $\mathrm{PM}_{2.5}$ as well as aerosol properties. The arrival of the dust can be identified through the rapid increase in $\mathrm{PM}_{2.5-10}$ accompanied by an increase in WS and a relatively steady WD. During the course of the second dust event, the $\mathrm{PM}_{2.5-10}$ level was observed to vary in puffs, which characterized the pattern of the dust deposition. The $\mathrm{PM}_{2.5}$ level was consistent with the $\mathrm{PM}_{2.5-10}$ level for the first puff of dust but from then on the pattern differed among each other for the rest of the duration of the event. It is worth noting that we found a strong correlation between duration of an event and the maximum $\mathrm{PM}_{10}$ or $\mathrm{PM}_{2.5-10}$ level in that event. For the post dust period, it was noted that the $\mathrm{PM}_{2.5}$ level increased dramatically due to atmospheric stagnancy brought about by the anticyclonic outflow. Regarding the $\mathrm{PM}_{2.5}$ chemical properties, sulfates were mostly contributed from dust transport while the rest were mainly related to vehicle exhausts. However, it must be noted that they were all enhanced by the atmospheric stagnancy in the post dust period. Finally, the aerosol size spectra for the three time periods of a dust event revealed that submicron particles dominated the pre-dust and post-dust periods, while supermicron particles were greatly enhanced during the dust period. A conversion of aerosol volume into mass by assuming a fixed particle density turned out to be around half of the monitored aerosol mass.

\section{Acknowledgements}

We are grateful for the support we received from the TEPA for the Taiwan aerosol supersite project. Although the Taiwan aerosol supersite is the official monitoring site of TEPA, the results of this paper are not peer-reviewed by TEPA, and the mentioning of instrument trade names does not constitute the endorsement of TEPA.

\section{References}

Boucher, O., Anderson, T.L., 1996. GCM assessment of the sensitivity of direct climate forcing by anthropogenic sulfate aerosols to aerosol size and chemistry. Journal of Geophysical Research 100, 26117-26134.

Chan, C.-C., Her, K.-Z., Huang, G.-H., Lee, C.-T., Wang, P.-Y., Cheng, T.-J., Huang, S.-L., Wang, C.-L., 2002. Health risk assessment of particulate matter. Taiwan EPA Technical Report, EPA-91-FA11-03-91DF02 (in Chinese).

Davies, C.I., 1979. Particle fluid interaction. Journal of Aerosol Science 10, 477-513.

Draxer, R.R., 1999. Hybrid single-particle lagrangian integrated trajectories (HYSPLIT): Version 4.0- User's Guide. NOAA Technical Memorandum ERL ARL-230, Air Resources Laboratory, Silver Spring, MD, USA.

Fang, M., Zheng, M., Wang, F., Chim, K.S., Kot, S.C., 1999. The long-range transport of aerosols from northern China to Hong Kong - a multi-technique study. Atmospheric Environment 33, 1803-1817.

Jaques, P.A., Ambs, J.L., Grant, W.L., Sioutas, C., 2004. Field evaluation of the differential TEOM monitor for continuous $\mathrm{PM}_{2.5}$ mass concentrations. Aerosol Science and Technology 38 (S1), 49-59.

Kim, B.G., Park, S.U., 2001. Transport and evolution of a winter-time Yellow sand observed in Korea. Atmospheric Environment 35, 3191-3201. 
Kim, K.W., Kim, Y.J., Oh, S.J., 2001. Visibility impairment during Yellow sand periods in the urban atmosphere of Kwangju, Korea. Atmospheric Environment 35, 5157-5167.

Koloutsou-Vakakis, S., Carrico, C.M., Li, Z., Rood, M.J., Ogren, J.A., 1999. Characterisation of aerosol properties and radiative forcing at an anthropogenically perturbed continental site. Physics and Chemistry of the Earth (C) 24, 541-546.

Lei, Y.-C., Chan, C.-C., Wang, P.-Y., Lee, C.-T., Cheng, T.-J., 2004. Effects of Asian dust event particles on inflammation markers in peripheral blood and bronchoalvelor lavage in pulmonary hypertensive rats. Environmental Research 95, 71-76.

Lin, T.H., 2001. Long-range transport of yellow sand to Taiwan in spring 2000: observed evidence and simulation. Atmospheric Environment 35, 5873-5882.

Ma, C.J., Kasahara, M., Tohno, S., Hwang, K.C., 2001. Characterization of the atmospheric aerosols in Kyoto and Seoul using PIXE, EAS and IC. Atmospheric Environment 35, 747-752.

McMurry, P.H., Wilson, J.C., 1982. Growth laws for the formation of secondary ambient aerosols: implications for chemical conversion mechanisms. Atmospheric Environment 16, 121-134.

Morawska, L., Thomas, S., Bofinger, N.D., Wainwright, D., Neale, D., 1998. Comprehensive characterisation of aerosols in a subtropical urban atmosphere: particle size distribution and correlation with gaseous pollutants. Atmospheric Environment 32, 2467-2478.

Mori, I., Iwasaka, Y., Matsunaga, K., Hayashi, M., Nishikawa, M., 1999. Chemical characteristics of free tropospheric aerosols over the Japan Sea coast: aircraft-borne measurements. Atmospheric Environment 33, 601-609.

Natsagdorj, L., Jugder, D., Chung, Y.S., 2003. Analysis of dust storms observed in Mongolia during 1937-1999. Atmospheric Environment 37, 1401-1411.

Okada, K., Kai, K., 2004. Atmospheric mineral particles collected at Qira in the Taklamakan Desert, China. Atmospheric Environment 38, 6927-6935.

Particle Measuring Systems Co., Inc., 2001. Operating Manual, Passive Cavity Aerosol Spectrometer Probe PMS Model
PCASP-X. Particle Measuring Systems Co., Inc., Boulder, CO, USA.

Ranz, W.E., Wong, J.B., 1952. Impaction of dust and smoke particles on surface and body collectors. Industrial and Engineering Chemistry 44, 1371-1381.

Rice, J., 2004. Comparison of integrated filter and automated carbon aerosol measurements at Research Triangle Park, North Carolina. Aerosol Science and Technology 38 (S2), 23-36.

Rupprecht and Patashnick Co., Inc., 2001a. Operating Manual, Series 8400 N Ambient Particulate Nitrate Monitor. February 2001, Revision A.

Rupprecht and Patashnick Co., Inc., 2001b. Operating Manual, Series 8400S Ambient Particulate Sulfate Monitor. June 2001, Revision A.

Rupprecht and Patashnick Co., Inc., 2002a. Operatin Manual, TEOM Series 1400a Ambient Particulate Monitor. March 2002, Revision B.

Rupprecht and Patashnick Co., Inc., 2002b. Operating Manual, Series 5400 Ambient Carbon Particulate Monitor. January 2002, Revision B.

Tratt, D.M., Frouin, R.J., Westphal, D.L., 2001. April 1998 Asian dust event: a southern California perspective. Journal of Geophysical Research 106, 18371-18379.

Uematsu, M., Duce, R.A., Prospero, J.M., Chen, L., Merrill, J.T., McDonald, R.L., 1983. Transport of mineral aerosol from Asia over the North Pacific Ocean. Journal of Geophysical Research 88, 5343-5352.

Weast, R.C., Astle, M.J. (Eds.), 1983. CRC Handbook of Chemistry and Physics. CRC Press, Inc., Boca Raton, Florida, USA.

Yang, H.-H., Cheng, S.-K., Hsieh, L.-T., 2004. Characterization of nitrate particulate dry deposition by vacuum-deposited thin film reaction method. Atmospheric Environment 38, 1785-1793.

Zhang, X.Y., Cao, J.J., Li, L.M., Arimoto, R., Cheng, Y., Huebert, B., Wang, D., 2002. Characterization of atmospheric aerosol over Xi An in the south margin of the Loess Plateau, China. Atmospheric Environment 36, 4189-4199. 